quality or ago by fluorescent effects. Many substances absorb ultra-violet rays and re-emit them as visible light of certain colours. The colours are specific and characteristic for each substance, but minute differences in chemical composition often cause large differences in the colours of tho emitted light. An egg, for example, changes its colour from mauve-red when it is newly laid to palo blue as it grows older, and a mixture of margarine and butter appears an unmistakably different colour from pure butter.

\section{A Geothermic Generating Plant}

ITALY has not confined its attention to doveloping hydro-electric power. At Bastardo in Umbria, Italian lignite is used to supply a largo electric power station. In addition, there has recently been exploitation of the natural steam resources of the borax mines geysers in Tuscany. The Larderello geothermic electric station is the best lnown. Antonio Giordano, in an article published in the Electrical Times of October 19, gives an account of its growth from 1905 to the present timo. Its capacity initially was 16,000 kilowatts. In tho past trelvo months, in association with the electrification of the Viareggio-Rome section of the Turin-Naples railway, running along the western Italian coasts, a new geothermic generating plant of $50,000 \mathrm{kT}$. capacity has been built. Its operation in the first few months has been so successful that the Borax Company of Larderello has placed orders for two now 12,000 kw. machines, for the necessary heat transformers, etc., and for the construction of a completely new power station at Castelnuovo, which. will house five generating sets each of $12,000 \mathrm{kw}$. When the new developments are completed, tho aggregate capacity of geothermic generating plants in Italy will amount to $135,000 \mathrm{kw}$., and the possibilities of further extensions are not exhausted. A problem connected with the exploitation of natural steam for power generation purposes is its purification. The diffeulty was solved success. fully by Prince Ginori Conti, chairman of the Lar. derello Company, by means of specially designed evaporator units. These consist of primary pipes through which the natural steam is circulated at a pressure of $3 \mathrm{kgm}$. per sq. cm., the pipes being immersed in water in a cylindrical tank. The energy is generated in the turbo-alternators at 25,000 volts and transmitted to the substations along the Viareggio-Rome railway, where it is converted to 3,000 volts direct current. The new station at C'astelnuovo will also serve this railway.

\section{Report of the Cambridge Observatory, 1938-39}

Tuz work carried out at the Cambridge Observatory under the directorship of Sir Arthur Eddington includes photo-electric observations for the purpose of testing the constancy of the light of stars similar in physical constitution to the sun (dwarf $G$ stars). With the Northumberland equatorial, 165 measures of double stars were made, 51 being less than $1^{\prime \prime}$ in separation. Dr. Woolley began laboratory experi. ments in preparation for a determination of the sun's apparent magnitude, planned, in conjunction with
Mr. C. R. Davidson, to be carried out in South Africa in 1940. The apparatus lad been brought to a stage at which it is possible to measure with a probable error of $0.01 \mathrm{mag}$. the transmission in sensibly monochromatic light of a dark glass cutting down threo magnitudes. The polarization of a spectrograph was carefully determined in soveral wavo-lengths, and $\mathrm{n}$ preliminary determination of the coefficient of reflection from an unsilvered glass surface was made. Both theoretical and observational work have been carried out by research students: Dr. M. Krook (Isaac Newton student) investigating certain problems invo.ving non-coherent absorption; D. S. Evans concluding his work on the influence of Stark effect on the centre-to-limb variation of the contours of the Balmer lines; J. Jeffreys (Isaac Nowton student) on photometric work in conjunction with Dr. Woolley's research on the sun's apparent magnitude, and $H$. Corben working on relativistic quantum theory. The Director has investigated the problem of how far the properties of a star of variable polytropic index are intermediate between thoso of polytropes corrosponding to the two extreme indexes. This research is given in Monthly Notices, 99, 4. By Grace of the Regent House on June 10, 1938, the Observatory was constituted a Department in the Faculty of Mathematics, and the Observatory Syndicate was discharged. Tho Syndicato had been in continuous existence for 109 years, an earlier Syndicato, appointed "for considering the propriety of building an Observatory", having met from 1818 until 1824.

\section{Plant Hormones in Horticulture}

THF chemical recognition of plant hormones was quickly followed by the synthesis of substances capable of initinting the formation of roots in the stems of many plants. Theso substances havo been used in plant propagation, causing almost in a 'catalytic' manner an acceleration of tho rooting process accompanied by a more profuse root system. H. L. Pearse has now reviewed the work of thirty or more investigators who have ondeavoured with considerable success to apply recent scientific discoveries to horticulture in this way ("Imperial 13ureau of Horticulture and Plantation Crops. Technical Communication No. 12: Plant Hormones and their Practical Importance in Horticulture". By Dr. H. L. Pearse. Pp. 88. Bibl. 248. 3s. 6d.). Thero follows a valuable index showing approximately ono thousand examples of propagation and the treatments used. This is not a complete list, and some difficulties in presenting the results of many workers in one table have been neatly overcome; but comparative reference would have been made easier by a standardized method of stating the concentrations employed. Results obtained by the additional use of vitamin $B_{1}$ (aneurin), known to influence the growth of excised roots in vitro, and other substances are also brought under review. The widespread use of aneurin is not recommended as yet, although at East Malling, as elsowhere, Pearse observed somo stimulation in the subsequent growth of rooted cuttings which had received small quantities of 
aneurin. The bulletin reports effects on other plant organs of these substances of possiblo application in horticulture. It is impossible to include all the latest work ; there is no mention here of totrahydronaphthylideno acetic acid, or of $\alpha$-naphthylacetamide, recently shown to be active substances inducing cell division and root formation, or of plants failing to respond to treatment the anatomy of which is under investigation at Kew. This bulletin forms a well. balanced review of the subject to date, and its valuo is increased by its practical outlook.

\section{Earthquake in Bulgaria}

Durnag the night of 'Thursday-Friday, October 19-20, strong earthquako shocks accompanied by a roaring sound wero reported from Orisovo near Tchirpan in south Bulgaria. Some alarm was caused among the inhabitants but no damage was reported, and thus the earthqualie appears to have been of about intensity VI on the Rossi-Forel scalo (oscillation of chandeliers, visible disturbance of trees and shrubs, somo startled persons leavo their dwellings). This area is definitely seismic, and violent local shocks were reported from the same region on April 14 and April 25, 1928. According to K. Jankov, of the Observatory at Sofia, the most active region is to the south-east of Kustendil, where 1,420 shocks occurred between the years 1749 and 1936, some of these being so severo as intensity VII on tho RossiForel scale (overthrow of movablo objects, fall of plaster, etc., but no damage to buildings). The majority of the shocks appear to have been of shallow focus, only affecting a small area and prob. ably being due to slipping along an active fault. The present shock may have been of $a$ similar nature.

\section{Earth Tremor near Ottawa}

AN earth tremor of intensity IV on the modified Mercalli scale (rattling of dishes, windows, doors) shook Ottawa on Friday, October 20. No damage was done. Small earth tremors are known to occur in eastern Canada from Baffin Bay to tho Great Lakes including Newfoundland, though the nearest active epicentres to Ottawa appear to bo those of Timiskaming (Quebec), where there was a shock on November 1, 1935, and in the region of the Sanguenay River, where shocks have been recorded from as early as Fobruary 5, 1663, and continuing to the present time. Further information concerning the shock of October 20 is awaited from the Dominion Observatory at Ottawa.

\section{Discovery of Comet Giacobina-Zinner}

Aw I.A.U. telegram from Copenhagen announces that thi comet was discovered by van Biesbroeck on October 15 at $1 \mathrm{~h} .17 \cdot 1 \mathrm{~m}$. U.T. Its position is given as R.A. 16h. $21 \mathrm{~m} .27 \cdot 4 \mathrm{~s}$., N. Dec. $1^{\circ} 18^{\prime} 53^{\prime \prime}$. It is described as diffuse with central condensation, magnitude 15. In the "Handbook of the British Astronomical Association, 1939", the elements and ephemeris of this comet are given by Mr. F. R. Cripps, who applied the perturbations of Jupiter and
Saturn to tho 1933 elements. The comet is very close to the predicted position, and it is only necessary to make the corrections for perihelion passage $0 \cdot 25 \mathrm{~d}$. later than that given in the "Handbook".

\section{Rapidly Moving Spots on the Planet Jupiter}

Mr. B. M. Pfek, president of tho British Astronomical Association and director of the Jupiter Section, has observed an outbreak of small dark spots on projections at the south edge or the North Temperate Belt of Jupiter. They appear to be rotating at such a speed that a complete rotation would take place in about 9 hours $50 \frac{1}{2}$ minutes. Thero is a remarkablo similarity between these spots and those which occurred in 1880, 1891 and 1929. Astronomers in possession of telescopes with apertures of 8 inches or more should be able to see theso spots.

\section{A Large Sunspot}

A LARGE sunspot appeared over the sun's east limb on October 19 and is now crossing to the west limb, which it will reach on November 1. The timo of central meridian passage of the spot is October $26 \cdot 0$, its latitude $8^{\circ}$ south and its aroa, corrocted for foreshortening, on October 20, was 1850 millionths of the sun's hemisphere.

\section{The Night Sky in November}

THE moon is new on November 11 at $7 \cdot 9 \mathrm{~h}$. and full on November 26 at $21 \cdot 9 h$. U.T. The bright star $\lambda$ Ceminorum (magnitude $3 \cdot 6$ ) is occultod on November 30, the disappearance as seen from Greenwich taking place at $2 \mathrm{~h} .22 \cdot 8 \mathrm{~m}$. at position angle $102^{\circ}$ from the north point, and the reappearance at $3 \mathrm{~h} .37 \cdot 8 \mathrm{~m}$. at $282^{\circ}$. Mars, Jupitor and Saturn are bright planets in tho evening or night sky. In mid-November, Mars souths at about $18 \mathrm{th}$., Jupiter at $20 \frac{1}{2} \mathrm{~h}$. and Saturn at $221 \mathrm{~h}$. Jupiter is in conjunction with the moon on November 21 at $22 \mathrm{~h}$. and Saturn on November 24 at 1 . Uranus is in opposition on November 13, when its distance from the earth is nearly 1,731 million miles. Neptuno, near the border between the constellations of Virgo and Leo, makes a near approach (about 20") to the eighth magnitude star $\mathrm{BD}+3^{\circ} 2549$. At about $21 \mathrm{~h}$. in the middle of the month, the Milky Way passes from the eastern to the western horizon through tho zenith of London. Tho most distant celestial object that can be seen with the naked eye-the Great Nebula in Andromeda-is on the meridian at an altitude of $79^{\circ}$. Vega is the brightest star in the north-west quadrant of the sky and Capella the brightest in the north-east. The Pleiades cluster is well above the eastern horizon, and Orion is then just rising. The Lconid meteors should be looked for about November 14-16; their radiant point, preceding $\gamma$ Leonis, rises about $23 \mathrm{~h}$. Tho meteors of this well-known shower aro characterized by swift flights and their greenish colour. Light variations in the variable star Algol ( $\beta$ Persei) may bo noticed about ono and a half hours before and after the following times of primary minima : November $14 \mathrm{~d} .3 \cdot 1 \mathrm{~h} . ; 16 \mathrm{~d} .23 \cdot 9 \mathrm{~h} . ; 19 \mathrm{~d}$. $20 \cdot 8 \mathrm{~h}$. and $22 \mathrm{~d}$. $17 \cdot 6 \mathrm{~h}$. 